University of San Diego

Digital USD

Biology: Faculty Scholarship

Department of Biology

Winter 1-3-1991

Total Body Water and Body Composition in Phalaropes and Other Birds

Hugh I. Ellis

Joseph R. Jehl Jr

Follow this and additional works at: https://digital.sandiego.edu/biology_facpub

Part of the Biology Commons, Ecology and Evolutionary Biology Commons, Ornithology Commons, and the Physiology Commons 


\title{
Total Body Water and Body Composition in Phalaropes and Other Birds
}

\author{
Abstract \\ Contrary to some reviews, total body water (TBW) may fall below the expected value of about $65 \%$ in birds \\ if measured as a percentage of total body mass. However, water constitutes a relatively stable proportion \\ (659\%-70\%) of body composition when measured as a percentage of lean body mass (LBM). We \\ demonstrate this by using data from two migratory phalaropes (Phalaropus tricolor and Phalaropus \\ lobatus), which exhibit inverse relationships between TBW and body mass and between TBW and fat \\ content. As the phalaropes fatten before migration, lipids increase but not at the expense of water, which \\ also increases with gains in lean tissue. The gain in lean dry mass with body size is also correlated with \\ migration. Because absolute water increases with body mass, TBW is a poor measure of hydration; \\ however, because of the inverse relationship between TBW and fat, TBW can predict body fat accurately if \\ a calibration curve is first generated. We provide equations that predict fat content in both species of \\ phalaropes suggest that water normally be reported not as TBW (a percentage of total body mass) but \\ preferably as "lean" body water (LBW, a percentage of lean body mass). In the absence of quantitative \\ estimates off at, we suggest that water be communicated in absolute amount, preferably with some \\ estimate of condition (fat).

\section{Disciplines} \\ Biology | Ecology and Evolutionary Biology | Ornithology | Physiology

\section{Notes} \\ Original publication information: \\ Ellis, H.I. and J.R. Jehl, Jr. 1991. Total body water and body composition in phalaropes and other birds. \\ Physiol. Zool. 64:973-984.
}




\title{
Total Body Water and Body Composition in Phalaropes and Other Birds
}

\author{
Hugh I. Ellis ${ }^{1}$ \\ Joseph R. Jehl, Jr. ${ }^{2}$
}

${ }^{1}$ Department of Biology, University of San Diego, Alcala Park, San Diego, California 92110; ${ }^{2}$ Hubbs-Sea World Research Institute, 1700 South Shores Road, San Diego, California 92109

Accepted 1/3/91

\begin{abstract}
Contrary to some reviews, total body water (TBW) may fall below the expected value of about $65 \%$ in birds if measured as a percentage of total body mass. How. ever, water constitutes a relatively stable proportion (65\%-70\%) of body composition when measured as a percentage of lean body mass (LBM). We demonstrate this by using data from two migratory phalaropes (Phalaropus tricolor and Phalaropus lobatus), which exhibit inverse relationships between TBW and body mass and between $T B W$ and fat content. As the phalaropes fatten before migration, lipids increase but not at the expense of water, which also increases with gains in lean tissue. The gain in lean dry mass with body size is also correlated with mi. gration. Because absolute water increases with body mass, TBW is a poor measure of hydration; however, because of the inverse relationship between TBW and fat, $T B W$ can predict body fat accurately if a calibration curve is first generated. We provide equations that predict fat content in both species of phalaropes. We suggest that water normally be reported not as TBW (a percentage of total body mass) but preferably as "lean" body water (LBW, a percentage of lean body mass). In the absence of quantitative estimates of fat, we suggest that water be communicated in absolute amount, preferably with some estimate of condi. tion (fat).
\end{abstract}

\section{Introduction}

Total body water (TBW) is the total water as a proportion of total body mass. We argue here that it is often misused because it is interpreted as a constant instead of a variable dependent on other body components, especially fat. For that reason, TBW cannot be a good measure of hydration. This is not a new message (see, e.g., Helms et al. 1967), but it is one that 
seems to have been forgotten. The early avian literature is devoid of references to TBW but treats water as one of a series of body components, although using various units of measure. For example, Odum (1960), Johnston and McFarlane (1967), and Yarbrough (1970) reported water in absolute values, whereas Odum, Rogers, and Hicks (1964), Helms et al. (1967), and McNeil (1970) used "water index," the ratio of water mass to dry, fat-free body mass.

The term TBW appeared in the avian literature only after about 1970, when it was determined by the arduous method of drying a carcass. It has since become increasingly common as a by-product of the isotopically labeled water method of determining field energetics. In such studies, the known dilution of the labeled water makes the calculation of TBW (or TOH space) quite easy. Although various sources of error have been identified in the use of labeled water to estimate TBW (Nagy and Costa 1980), no one seems to have questioned the value of TBW itself, in spite of the warnings of Packard and Boardman (1988) regarding the danger of using proportions and percentages in physiological measures. Below we demonstrate the problem, using our own data on two species of phalaropes; then we give examples in the literature of how TBW can be misleading. Finally, we suggest when TBW may in fact be of value in physiological studies.

\section{Material and Methods}

Wilson's phalarope (Phalaropus tricolor) and the red-necked phalarope (Phalaropus lobatus) are two shorebirds that lay on differing amounts of fat preparatory to migrating out of Mono Lake, California, which both species use as a staging area. Adult birds were collected (by J.R.J.) in the summers of 1980,1981 , and 1989. No prefledging birds were used in this study because of differences in hydration that have been noted previously (Hughes, Roberts, and Thomas 1987; Duncan and Gaston 1988). Measurements taken in the field included mass as well as bill, tarsus, and wing lengths. After the fresh weights were determined, the body cavities of the birds were opened, they were sexed, and dried to constant weight at $60^{\circ} \mathrm{C}$ in a Thelco Precision Model 19 hot-air oven and weighed again to obtain, as the difference from fresh weight, TBW. The dried carcasses were then ground to a fine powder in a food blender and soaked for $2 \mathrm{~d}$ in two baths of anhydrous ether, which removed about $95 \%$ of all lipids except phospholipids, which account for only about $1.5 \%$ of the lean dry mass (Dobush, Ankeny, and Krementz 1985). The entire carcasses were used for lipid extraction in the birds collected in 1980-1981, whereas only a 10-15-g aliquot of the powder was used in 1989. 
The residue was dried again and weighed, which gave lean dry body mass (LDM) or, in the case of the 1989 birds, a known fraction of it. Lean body mass (LBM) is this mass plus the weight of water previously measured.

A verification study using three Wilson's phalaropes and four eared grebes (Podiceps nigricollis) was done in 1989 on the lipid extraction method to ascertain whether complete extractions were being achieved. We found that, while a single bath removed a variable amount of lipid, two baths consistently removed nearly $95 \%(94.2 \% \pm 4.2 \%)$ of the lipid, and three baths removed nearly all of it $(97.4 \% \pm 4.3 \%)$. Additional baths did not increase extraction measurably. The efficacy of ether in fat extractions has been documented by Dobush et al. (1985). All of our data presented in this paper have been adjusted for the slight underestimate of lipids given by our method. Because there are significant sexual size differences in phalaropes (Jehl and Murray 1986), data for each sex were analyzed separately.

\section{Results}

In both species of phalaropes, TBW was inversely correlated with mass (fig. 1). This relationship was significant for females $(P<0.01)$ of both species and for male Wilson's phalaropes $(P<0.01)$ but not for male red-necked phalaropes. We consider the lack of significance in the latter group to be a result of the small range of body mass in our sample. Both sexes of both
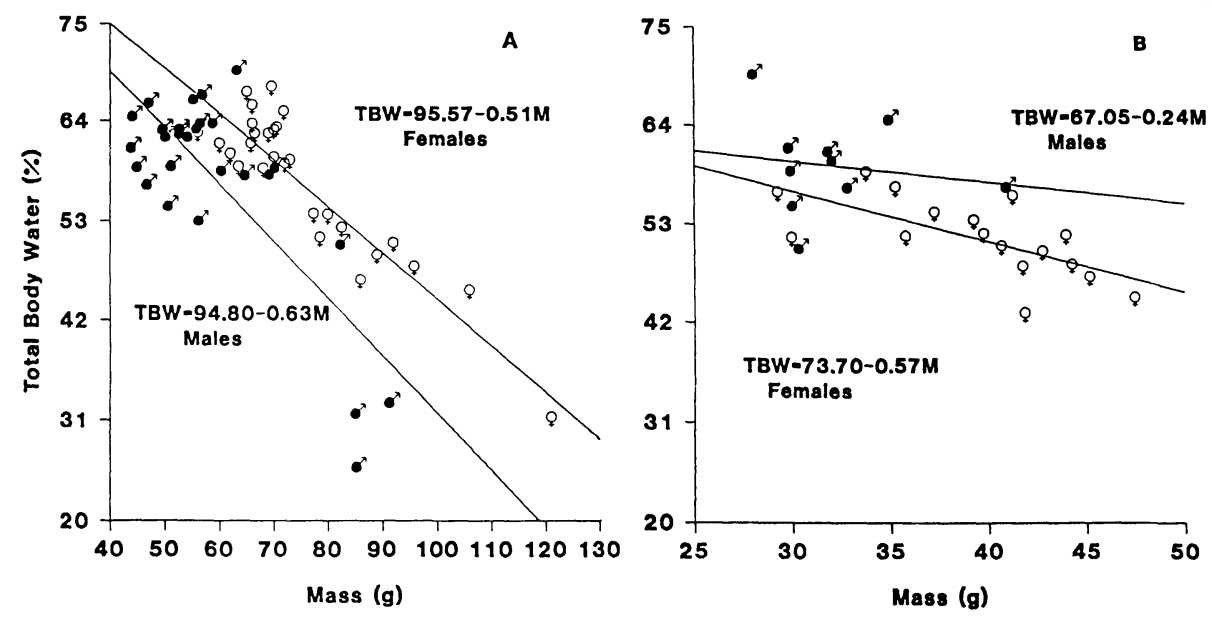

Fig. 1. Total body water (TBW) as a function of mass. A, Wilson's phalaropes; $\mathrm{B}$, red-necked phalaropes. Note differences in the mass scales. The relationship for males in $\mathrm{B}$ is not significant; see text. 
species also showed an inverse and significant $(P<0.01)$ correlation between TBW (a percentage) and lipids in the body, following the prediction of Helms et al. (1967). Male and female Wilson's phalaropes do not differ in the relationship between TBW (\%) and fat $(\mathrm{g})$; for both sexes combined (fig. 2A),

$$
\text { fat }=81.94-1.23 \mathrm{TBW}
$$

Male and female red-necked phalaropes appear to have different slopes, although this might be affected by the absence of values at low TBW (high) fat for male red-necked phalaropes (fig. 2B). For males,

$$
\text { fat }=23.93-0.34 \mathrm{TBW}
$$

for females,

$$
\text { fat }=44.04-0.69 \mathrm{TBW}
$$

and for both sexes of red-necked phalaropes,

$$
\text { fat }=34.89-0.51 \mathrm{TBW} \text {. }
$$
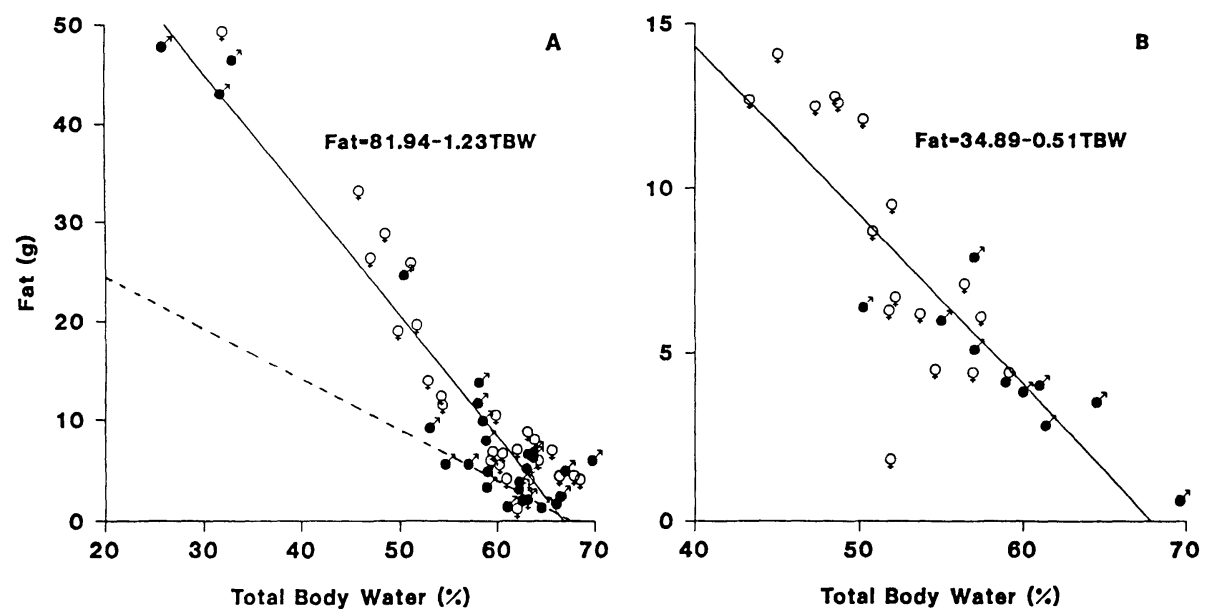

Fig. 2. Fat as a function of TBW. A, Wilson's phalaropes. The solid line and equation describe the relationship for both sexes. Because the scales for the two species are different, the relationship between fat and TBW in the combined sexes of red-necked phalaropes is presented as a dashed line for comparison. B, Red-necked phalaropes. The solid line (seen as a dasbed line in A) and equation represent the sexes combined. Unlike Wilson's phalaropes, the sexes are described by different equations, which are in the text. 
The fattest bird in our analysis, a female Wilson's phalarope (mass $=120 \mathrm{~g}$ and lipid content $=41 \%$ ) had a TBW of $31.4 \%$, which appears to be the lowest value of TBW yet recorded.

To clarify the relationship between body water and lipids, we plotted the ratio of water $(\mathrm{g})$ to $\mathrm{LBM}(\mathrm{g})$ as a function of mass; we refer to this ratio as lean body water (LBW) and present it, like TBW, as a percentage (fig. 3). The ratio was independent of mass for the sexes of both species considered separately or together, except for female Wilson's phalaropes, in which there was a rather small slope $(-0.123)$ that was significantly different from zero $(0.05>P>0.01)$. That slope was only significant because of the inclusion of our largest female, which, even on a LBM basis, was only $51.5 \%$ water. When the sexes were combined, the LBW of Wilson's phalaropes $(N$ $=55)$ was $67.57 \% \pm 4.18 \%$, and that of red-necked phalaropes $(N=27)$ was $65.74 \% \pm 3.73 \%$. The mean values are not significantly different.

Having shown that TBW for most of our sample was a constant proportion of lean body mass (LBM) regardless of size, we considered whether fat might somehow be displacing water. In a study of the morphometrics of these species, we plotted fresh body mass against wing length (a conservative index of body size). We found that body mass actually varied independently of body size as estimated by wing length in all red-necked phalaropes and in female Wilson's phalaropes. However, in male Wilson's phalaropes, fresh body mass was directly linked to wing length $(P<0.05)$. Using data for only female Wilson's phalaropes (where body mass was independent of
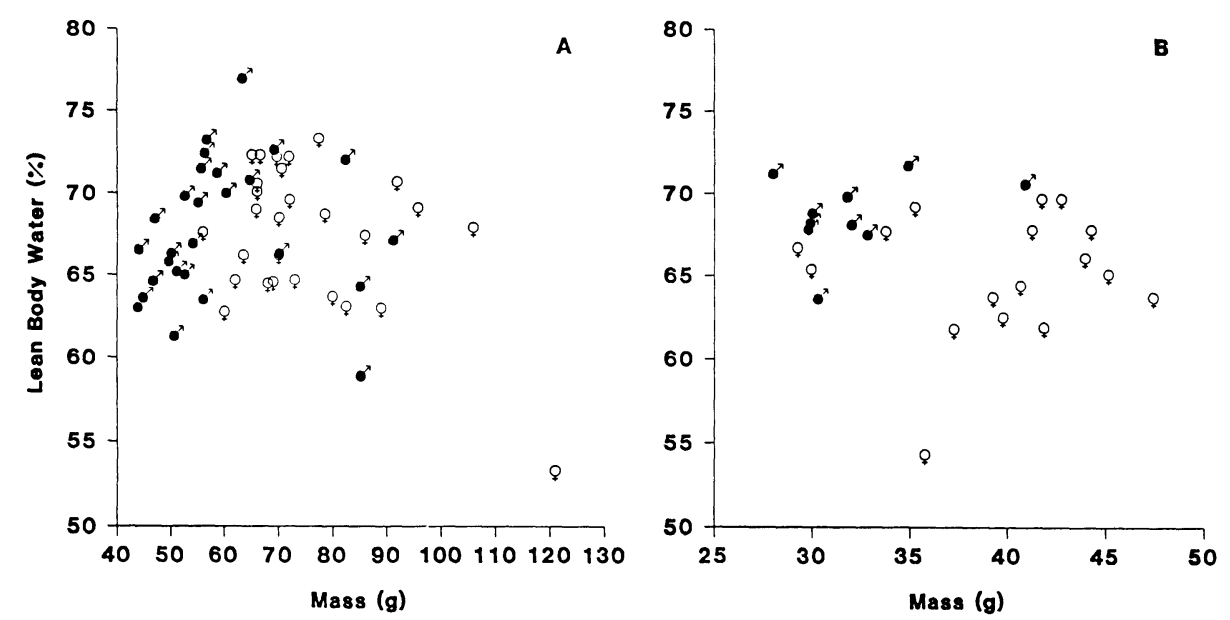

Fig. 3. The relationship between LBW and mass for (A) Wilson's and (B) red-necked phalaropes. Lean body water is calculated as water $(g)$ divided by LBM in grams. This relationship is not significantly different from zero in the combined sexes of both species; see text. 
body size) and female red-necked phalaropes (where our size range is greater and for consistency with the other species), we plotted both lean dry mass (LDM = LBM - water) and lipids as a function of (fresh) mass (fig. 4). In both species, lipids and LDM increased with body mass, although lipid content increased more rapidly. The increase in LDM, however, meant that water was also increasing because water is a constant proportion of lean body mass in these birds. We conclude that, as these birds increase in size and in fat content prior to migration, water is not displaced as TBW drops but, rather, increases because of the concomitant increase in muscle mass. Furthermore, both components increase more in Wilson's phalaropes; lipids increase $27.6 \%$ more in Wilson's than red-necked phalaropes and LDM increases $40 \%$ more.

\section{Discussion}

\section{Body-Component Implications}

Our data show that, even as these phalaropes fatten, they continue to put on lean body components (i.e., muscle). Our results are consistent with recent work on migratory birds (McNeil 1970; Marsh and Storer 1981; Davidson 1984; Johnson et al. 1989) but differ from the findings of Connell, Odum, and Kale (1960) and Hicks (1967), who argued that the nonfat components of migratory birds were constant over time, and that fluctuations in weight were due to lipids (see also Odum 1965).
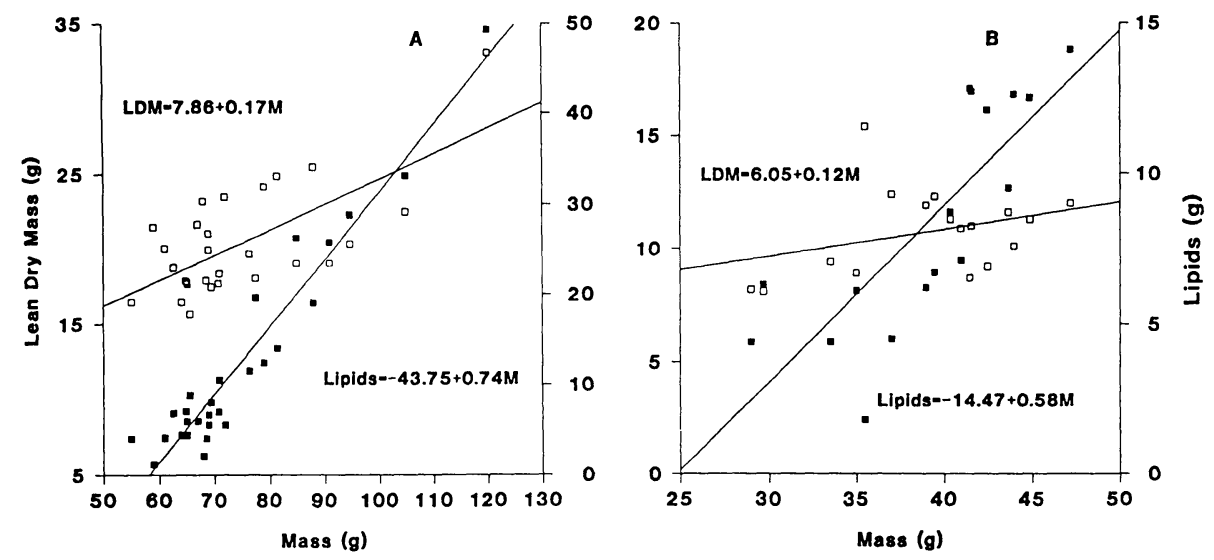

Fig. 4. Comparison of LDM and lipids to mass in females only of (A) Wilson's and (B) red-necked phalaropes. Open symbols, LDM; closed symbols, lipids. Note the difference in scales of all axes in the two species. 
We think the patterns of increase in the two species of phalaropes are related to migration patterns. Red-necked phalaropes probably move to their wintering grounds by a series of relatively short flights, none exceeding perhaps a few hundred kilometers (Jehl 1986). They lay on moderate fat and muscle, whereas adult Wilson's phalaropes, which undertake a nonstop migration of about $4,800 \mathrm{~km}$ from the United States to South America (Jehl 1988), lay on immense stores of fat and greater muscle mass before departing. As an illustration (fig. 4), a 50\% increase in mass would be accompanied by a $97 \%$ increase in fat in Wilson's phalaropes but would be accompanied by an $82 \%$ increase in fat in red-necked phalaropes. The gain in LDM by Wilson's phalaropes is even more impressive: for a $50 \%$ increase in mass, they gain $28 \%$ LDM compared to $18 \%$ for red-necked phalaropes. Whether this increased LDM mass represents flight muscle added for migration or a protein energy store for it is unclear (see Davidson and Evans 1989).

Several workers (McNeil and de Itriago 1968; McNeil 1970; Davidson 1983, 1984; Johnson et al. 1989) have suggested adaptive changes in water content associated with migration. They have asserted that real dehydration ("premigratory dehydration") occurs in some long-distance migrants that become obese prior to migration. The purpose, ostensibly, is to maximize flight range (i.e., fat content) while minimizing load (i.e., total body mass) Wilson's phalarope is a very long distance migrant, and the largest individua we studied (female, $120 \mathrm{~g}$ ) indeed displays a low water content in figur $3 A$. It only had a TBW of $31.4 \%$ and an LBW of $51.5 \%$. At present, we ar reluctant to assign its low water content to premigratory dehydration because a small (35.5 g) and very lean female red-necked phalarope also showed: low water content with $\mathrm{TBW}=51.6 \%$ and $\mathrm{LBW}=54.3 \%$ (fig. $3 \mathrm{~B}$ ). Reducer body water associated with hydration state obviously can occur in bird irrespective of body fat. The extent to which dehydration, including pre migratory water loss, may be affected by migratory behavior in these bird is currently under study by us.

\section{Problems Involving TBW}

Even though TBW (a percentage) decreases with an increase in body mas in both species of phalaropes, total water ( $g$ ) actually increases. This because any body component that contains little or no water and that ca vary in amount (e.g., fat or perhaps feathers) will affect TBW. First note by Helms et al. (1967) in the avian literature, the variability of fat explair why water content as a body component is stable only when based on LB (as shown in fig. 3 and by Rogers and Odum [1964], Davidson [1982], ar. 
Degen, Pinshow, and Shaw [1984]) or LDM (McNeil 1970). This also explains certain anomalies in the literature.

Skadhauge (1981, tables 1.1 and 1.2) found that, for 15 species of birds, TBW averaged $64.2 \% \pm 8.5 \%$, and he suggested that TBW should be about $60 \%$ in adult birds regardless of mass. Mahoney and Jehl (1984) reached a similar conclusion from a largely independent data set comprising 22 species of marine birds (TBW $=62.5 \% \pm 5.3 \%$ ). Finally, Hughes et al. (1987) compared 10 species of birds with salt glands to 10 species without and found TBW in the two groups $(66.8 \% \pm 1.6 \%$ and $63.0 \% \pm 2.7 \%$, respectively) to be statistically indistinguishable. Except for one unexplained report for the burrowing owl (Athene cunicularia) at 41\% (Chapman and McFarland $1971)$, there seemed to be no indication that avian TBW could fall below $60 \%$ of body mass. However, recent studies on some procellariiform birds have shown levels of TBW well below 60\% (table 1). Adams et al. (1986) suggested that the low TBW in the wandering albatross might result from a high feather-to-body mass ratio in these long-winged birds. Pettit et al. (1988) agreed but also suggested that low TBW might result from large fat deposits, which are not unusual in some seabirds. Although measurements of lipids were not presented in these or most earlier studies of TBW, lipids'

TABLE 1

Total body water in Procellariiformes

\begin{tabular}{|c|c|c|}
\hline Species & $\mathrm{TBW}^{\mathrm{a}}$ & Source \\
\hline \multicolumn{3}{|l|}{ Wandering albatross } \\
\hline (Diomedea exulans) & 47.5 & Adams, Brown, and Nagy 1986 \\
\hline \multicolumn{3}{|l|}{ Laysan albatross } \\
\hline (Diomedea immutabilis) & 47.5 & Pettit et al. 1988 \\
\hline \multicolumn{3}{|l|}{ Grey-headed albatross } \\
\hline (Diomedea chrysostoma) & 57.9 & Costa and Prince 1987 \\
\hline \multicolumn{3}{|l|}{ Wilson's storm-petrel } \\
\hline (Oceanites oceanicus) & 45.9 & Obst, Nagy, and Ricklefs 1987 \\
\hline \multicolumn{3}{|l|}{ Leach's storm-petrel } \\
\hline (Oceanites leucorboa) & $38.9-50.4$ & $\begin{array}{l}\text { Ricklefs, Roby, and Williams } \\
1986\end{array}$ \\
\hline \multicolumn{3}{|l|}{ Northern fulmar } \\
\hline (Fulmarus glacialis) & 64.8 & Mahoney and Jehl 1984 \\
\hline
\end{tabular}

${ }^{a}$ Calculated as the percentage of total body water in total body mass. 
role in low TBW values is supported by more "typical" values seen in Procellariiformes that were lean (table 1): the gray-headed albatrosses (TBW $=57.9 \%$ ) were probably lean (D. P. Costa, personal communication), and the northern fulmar ( $\mathrm{TBW}=64.8 \%$ ) was a lean bird that had died in captivity (J. R. Jehl, personal observation). Thus, the assertions of Skadhauge (1981) and Mahoney and Jehl (1984), although generally correct, are relevant only to lean birds.

Recognition of the potential variability of TBW should prevent its use in ways that are either misleading or not useful. For example, Gales (1989), in a validation study of isotope turnover, stated that $\mathrm{TBW}$ of little penguins (Eudyptula minor) averaged 62.6\%, "a figure that is typical of normally hydrated adult birds," and cited Skadhauge (1981) and Mahoney and Jehl (1984) in support. We contend that no simple value can represent a "normally hydrated" bird except on a fat-free basis. In fact, Gales's birds ranged in TBW from $57 \%$ to $71 \%$. Some readers might infer that these penguins are subject to various levels of dehydration; we suspect, however, a wide variation in fat content, although that is not reported. Mahoney and Jehl (1984) summarized the literature on TBW in marine birds without taking into account differences that might come from body composition. Some of the birds in that report were lean; others were not. Hughes et al. (1987, p. 489) made a regression line of the Mahoney and Jehl data to predict TBW in other species. However, that is unjustified, because TBW is not a constant but varies with other body components.

\section{The Use of TBW}

Although TBW is not a good measure of hydration in animals that show variation in lipid content, it can be used as a reasonable predictor of body fat if a calibration curve can be generated. Once established, this relationship can give fairly accurate estimates of fat content from only TBW. This has been shown for a few species of birds (see Johnson et al. 1985), young elephant seals (Mirounga angustirostris) (Ortiz, Costa, and LeBoeuf 1978), and humans (Frisch 1988). However, in all these cases, the curve, which is species specific, must be known before additional measures of TBW have any value in predicting fat content (in grams). In the case of the two phalaropes studied here, we can now suggest predictive equations (fig. 2).

\section{Conclusions}

Total body water is a stable proportion of LBM only, averaging $65 \%-70 \%$ in birds. It is not a good estimate of hydration or, conversely, dehydration 
in the absence of information about fat content, because water and lipids are inversely related when presented as proportions of total body mass. This relationship suggests that $\mathrm{TBW}$ can be used to predict the percentage of fat in an animal if a calibration curve has been established for that species. In the absence of specific information, TBW is expected to be lower in longdistance migrants, hibernators, and species that store fat as a protection against an unpredictable food supply. In studies in which degree of hydration or water flux is important, we suggest that values of body water be reported as a percentage of LBM. Alternatively, water (and other body components) may be reported in absolute terms, in order to avoid the problems noted above and more generally by Packard and Boardman (1988). Furthermore, if $\mathrm{TBW}$ is reported, at least a qualitative statement about fat content should be included, especially where TBW $<60 \%$.

\section{Acknowledgments}

This research was supported in part by the Los Angeles Department of Water and Power. S. I. Bond prepared the figures and, with B. Hale, assisted in laboratory work. R. McNeil, T. Williams, and R. Davis provided helpful comments on an earlier draft. We acknowledge the cooperation of the San Diego State University Life Science Computer Facility for providing data management, analysis, and reporting support.

\section{Literature Cited}

Adams, N. M., C. R. Brown, and K. A. NaGY. 1986. Energy expenditure of free-ranging wandering albatrosses Diomedea exulans. Physiol. Zool. 59:583-591.

Chapman, T. E., and L. F. McFarland. 1971. Water turnover in Coturnix quail with individual observations on a burrowing owl, Petz conure, and vulturine fish eagle. Comp. Biochem. Physiol. 39A:653-656.

Connell, C. E., E. P. Odum, and H. Kale. 1960. Fat-free weights of birds. Auk $77: 1-9$.

Costa, D. P., and P. A. Prince. 1987. Foraging energetics of grey-headed albatross Diomedea chrysostoma at Bird Island, South Georgia. Ibis 128:149-158.

Davidson, N. C. 1982. Changes in the body-condition of redshanks during mild winters: an inability to regulate reserves. Ringing and Migration 4:51-62.

- 1983. Formulae for estimating the lean weight and fat reserves of live shorebirds. Ringing and Migration 4:159-166.

1984. How valid are flight range estimates for waders? Ringing and Migration 5:49-64. 
Davidson, N. C., and P. R. Evans. 1989. Prebreeding accumulation of fat and muscle protein by Arctic-breeding shorebirds. Proc. XIX Int. Ornithol. Congress Ottawa 1989:342-352.

Degen, A. A., B. Pinshow, and P. J. Shaw. 1984. Must desert chukars (Alectoris chukar sinaica) drink water? Water influx and body mass changes in response to dietary water content. Auk 101:47-52.

Dobush, G. R., C. D. Ankeny, and D. G. Krementz. 1985. The effect of apparatus, extraction time, and solvent type on lipid extractions of snow geese. Can. J. Zool. 63:1917-1920.

DunCAN, D. C., and A. J. Gaston. 1988. The relationship between precocity and body composition in some neonate alcids. Condor 90:718-721.

FrISCH, R. E. 1988. Fatness and fertility. Sci. Am. 258:88-95.

Gales, R. 1989. Validation of the use of tritiated water, doubly labeled water, and ${ }^{22} \mathrm{Na}$ for estimating food, energy, and water intake in little penguins, Eudyptula minor. Physiol. Zool. 62:147-169.

Helms, C. W., W. H. Aussiker, E. B. Bower, and S. D. Fretwell. 1967. A biometric study of major body components of the slate-colored junco, Junco byemalis. Condor 69:560-578.

HICKS, D. L. 1967. Adipose tissue composition and cell size in fall migratory thrushes (Turdidae). Condor 69:387-399.

Hughes, M. R., J. R. Roberts, and B. R. Thomas. 1987. Total body water and its turnover in free-living nestling glaucous-winged gulls with a comparison of body water and water flux in avian species with and without salt glands. Physiol. Zool. 60:481- 491 .

JeHL, J. R., JR. 1986. Biology of red-necked phalaropes (Phalaropus lobatus) at the western edge of the Great Basin in fall migration. Great Basin Nat. 46:185-197.

- 1988. Biology of the eared grebe and Wilson's phalarope in the nonbreeding season: a study of adaptations to saline lakes. Stud. Avian Biol. 12:1-74.

Jehl, J. R., JR., and B. G. Murray, Jr. 1986. The evolution of normal and reversed sexual size dimorphism in shorebirds and other birds. Curr. Ornithol. 3:1-86.

Johnson, D. H., G. L. Krapu, K. J. Reinecke, and D. G. JoRde. 1985. An evaluation of condition indices for birds. J. Wildl. Manage. 49:569-575.

Johnson, O. W., M. L. Morton, P. L. Bruner, and P. M. Johnson. 1989. Fat cyclicity, predicted migratory flight ranges, and features of wintering behavior in Pacific golden-plovers. Condor 91:156-177.

Johnston, D. W., and R. W. MCFarlane. 1967. Migration and bioenergetics of flight in the Pacific golden plover. Condor 69:156-168.

McNeil, R. 1970. Hivernage et estivage d'oiseaux aquatiques nord-americains dans le nord-est du Venezuela (mué, accumulation de graisse, capacité de vol et routes de migration). l'Oiseaux et la R.F.O. 40:185-302.

McNeil, R., and M. C. DE ITRIaGo. 1968. Fat deposition in the scissors-tailed flycatcher (Muscivora t. tyrannus) and the small-billed elaenia (Elaenia parvirostris) during the austral migratory period in northern Venezuela. Can. J. Zool. 46:123-128.

Mahoney, S. A., and J. R. Jehl, JR. 1984. Body water content in marine birds. Condor 86:208-209.

Marsh, R. L., and R. W. Storer. 1981. Correlations of flight-muscle size and body mass in Cooper's hawks: a natural analog of power training. J. Exp. Biol. 91:363368. 
NAGY, K. A., and D. P. Costa. 1980. Water flux in animals: analysis of potential errors in the tritiated water method. Am. J. Physiol. 238:R454-R465.

Obst, B. S., K. A. NAGY, and R. E. Ricklefs. 1987. Energy utilization by Wilson's storm-petrel (Oceanites oceanicus). Physiol. Zool. 60:200-210.

Odum, E. P. 1960. Lipid deposition in nocturnal migrant birds. Proc. XII Int. Ornithol. Congress Helsinki 1958:563-576.

1965. Adipose tissue in migratory birds. Pages $37-43$ in Handbook of physiology. Sec. 5. Adipose tissue. American Physiological Society, Washington, D.C.

Odum, E. P., D. T. Rogers, and D. L. Hicks. 1964. Homeostasis of the nonfat components of migrating birds. Science 143:1037-1039.

Ortiz, C. L., D. Costa, and B. J. LeBoeuf. 1978. Water and energy flux in elephant seal pups fasting under natural conditions. Physiol. Zool. 51:166-178.

PACKard, G. C., and T. J. Boardman. 1988. The misuse of ratios, indices, and percentages in ecophysiological research. Physiol. Zool. 61:1-9.

Pettit, T. N., K. A. Nagy, H. I. Ellis, and G. C. Whittow. 1988. Energy expenditure of incubating and foraging Laysan albatross. Oecologia 74:546-550.

Ricklefs, R. E., D. D. Roby, and J. B. Williams. 1986. Daily energy expenditure by adult Leach's storm-petrels during the nesting cycle. Physiol. Zool. 59:649-660.

Rogers, D. T., JR., and E. P. Odum. 1964. Effect of age, sex, and level of fat deposition on major body components in some wood warblers. Auk 81:505-513.

SKADHAUGE, E. 1981. Osmoregulation in birds. Springer, New York. 203 pp.

Yarbrough, C. G. 1970. Summer lipid levels of some subarctic birds. Auk 87:100110. 